\title{
Article \\ Evaluation of Positive Socio-Economic Phenomena in Territorial Systems of Ecological Stability (Case Study)
}

\author{
Renáta Rákayová ${ }^{1,2, *}$ and Milena Moyzeová ${ }^{3}$ \\ 1 ESPRIT s. r. o., 96901 Banská Štiavnica, Slovakia \\ 2 Faculty of Natural Sciences, Constantine the Philosopher University in Nitra, 94901 Nitra, Slovakia \\ 3 Institute of Landscape Ecology, Slovak Academy of Science, 81438 Bratislava 1, Slovakia; \\ milena.moyzeova@savba.sk \\ * Correspondence: rakayova@esprit-bs.sk
}

check for updates

Citation: Rákayová, R.; Moyzeová, M. Evaluation of Positive Socio-Economic Phenomena in Territorial Systems of Ecological Stability (Case Study). Land 2022, 11, 120. https://doi.org/10.3390/ land 11010120

Academic Editor: Shiliang Liu

Received: 30 November 2021

Accepted: 6 January 2022

Published: 12 January 2022

Publisher's Note: MDPI stays neutral with regard to jurisdictional claims in published maps and institutional affiliations.

Copyright: (C) 2022 by the authors. Licensee MDPI, Basel, Switzerland. This article is an open access article distributed under the terms and conditions of the Creative Commons Attribution (CC BY) license (https:// creativecommons.org/licenses/by/ $4.0 /)$.

\begin{abstract}
One of the active tools that increase the ecological stability of a country are projects related to territorial systems of ecological stability (TSES). An important part of the elaboration of TSES projects is also the evaluation of positive socio-economic phenomena (PSEP). Their evaluation is important for the design of measures that will ensure its proper functioning. The PSEP enter, the spatial system as elements that fulfill important ecological functions and help preserve the natural resources, gene pool, ecological stability and diversity of the landscape. Therefore, it is necessary to maintain their functions in the future. The theoretical and methodological basis for the evaluation of PSEP within TSES is the LANDEP methodology. They are not unique in the area, and they can occur in various combinations. Based on varied combinations of positive phenomena ensuing from nature conservation, protection of water sources, forest and soil sources, mineral resources and cultural or historical resources there are various types of territories with different landscape ecological significance and different ecological stability. The resulting combinations are a limiting input for the proposed activities and must be respected when processing ecostabilization measures within TSES projects. The presented study presents a landscape ecological evaluation of socio-economic phenomena of nature protection and natural resources in a project of the local system of ecological stability which was developed for the agriculturally intensively used area of Dolný Lopašov. It assesses the legal status of the territory and specifies and spatially expresses areas with different representations of important landscape elements which come under legislative protection. Based on the occurrence, abundance, character and combinations of PSEP occurring in the cadastral area of the commune Dolný Lopašov, this specifies 8 degrees of landscape ecological significance. Significance categories form the basis for the overall classification of the territory required for the processing of TSES projects at the local level. The obtained results must be applied to the proposals of measures to increase ecological stability, especially in the central and southern part of the cadastral area of the commune Dolný Lopašov.
\end{abstract}

Keywords: local system of ecological stability; positive socio-economic elements; landscape ecological importance; Dolný Lopašov community

\section{Introduction}

The issue of ecological stability assessment, whether in the form of building ecological networks, green infrastructure or TSES, has a rich history. At the beginning of the 21st century, there were at least 42 different eco-networking initiatives in Europe, seven of them at national level (Boitani et al., 2007) [1]. According to Buček (2013) [2], the Czechoslovak conception of TSES (Buček, Lacina, 1984 [3], Míchal 1992 [4], Buček, Lacina 1993 [5], Maděra, 2010 [6], Miklós, 2010 [7]) belongs to the longest applied methodology of creating ecological networks. Already in 1985, the Institute of Experimental Biology and Ecology of the Slovak Academy of Science, in cooperation with URBION, prepared the Ecological General of the 
Czechoslovak Socialist Republic, part of the SSR (Miklós et al., 1985) [8], an integral part of which was the elaboration of the territorial system of ecological stability. The concept of the TSES was approved in 1991. The concept contained the basic starting points of the TSES, the criteria for their selection and the hierarchical level. In 1992, the first concept of the General supra-regional TSES for the territory of Slovakia was prepared (Húsenicová et al., 1992 [9]). Following the General TSES, in 1996 a proposal for the national ecological network NECONET (IUCN, 1996) was developed [10]. The NECONET proposal was based on the concept of building a European ecological network, the so-called EECONET (Jongman, 1995) [11], which was based on the Dutch concept of ecological networking. EECONET was mentioned in Bennett $(1991,1995)$ [12,13], Colmenares at al. (1994) [14], Salman (1993) [15], Gleichman-Verheijen (1994) [16], Stuffmann (1994) [17], Liro (1995) [18], Horlings (1995) [19], Jongman et al. (2004) [20] and Ferranti et al. (2010) [21]. The NATURA 2000 network focused on the protection of habitats and representative species of plants and animals in their natural environment, which also solves the problem of the nationwide provision of ecological stability of the landscape and biodiversity.

Nowadays, the creation of territorial systems of ecological stability (TSES) in the Slovak Republic is set by the legislative adjustment in Act No. 543/2002 Coll. [22] on nature and landscape protection, as amended in $\S 2$, paragraph 2, letter a), as a spatial structure of interconnected ecosystems, their components and elements ensure the diversity of conditions and forms of life in the country. The basis of this system is represented by biocentres, biocorridors and interaction elements of supra-regional, regional and local importance. The TSES also includes a proposal for a system of ecostabilization measures aimed at the ecologically optimal organization and use of the landscape. At present, regional territorial systems of ecological stability are being developed for 79 districts of Slovakia, and local territorial systems of ecological stability at the local level mainly within the framework of landscaping projects. Extension of the TSES projects then provides important parts of the spatial planning documents which have the major goal of creating appropriate conditions which increase biodiversity at the supra-regional, the regional and the local level. The local territorial systems have a great importance for landscape ecological stabilization because they form the densest national network which builds hierarchical element levels (Buček, 2013) [2]. The design of the local systems of ecological stability (L-SES) is especially important in the agrarian sphere where TSES elements (biocentres, biocorridors and interaction elements) contribute to an increase in the stability of intensively used agricultural land characterized by often low vegetation. Here, the Dolný Lopašov model design is a perfect example of appropriate L-SES processing in the agrarian landscape. (Špulerová et al., 2020) [23]. L-SES are most often processed in scales of 1: 10,000 or 1: 5000. L-SES represents a specific landscape ecological basis for the elaboration of spatial plans of municipalities, settlement zones, as well as land readjustment projects.

From this aspect, the evaluation of PSEP is important in the identification of important landscape elements, which not only increase the ecological stability of a territory but often form the framework of the territorial system of ecological stability in the country. Equally, knowledge of PSEP is important in the design of management measures, in which it is necessary to incorporate the restrictions and limits arising from legislation on the protection of nature, natural resources and the environment.

The aim of this paper is to present an evaluation of PSEP that enter the newly proposed methodological process of creating a local territorial system of ecological stability (Miklós et al., 2020) [24] which is based on the specification of landscape structures with varying degrees of legislative protection, types of landscapes with different landscape ecological significance and degree of ecological stability.

\section{Materials and Methods}

\subsection{Socio-Economic Characteristics of the Commune Dolný Lopašov}

Figure 1 highlights that the Dolný Lopašov community is part of the Piešt'any district administrative division in the larger Trnava region. The oldest recorded national settlement 
emerged in the Late Stone Age, and Dolný Lopašov is first mentioned in the 1934 'Lopasow' document. The early inhabitants were engaged in agriculture, viticulture, fruit growing and cattle breeding, and their fabric weaving included an embroidery workshop (Kol., 2005) [25].

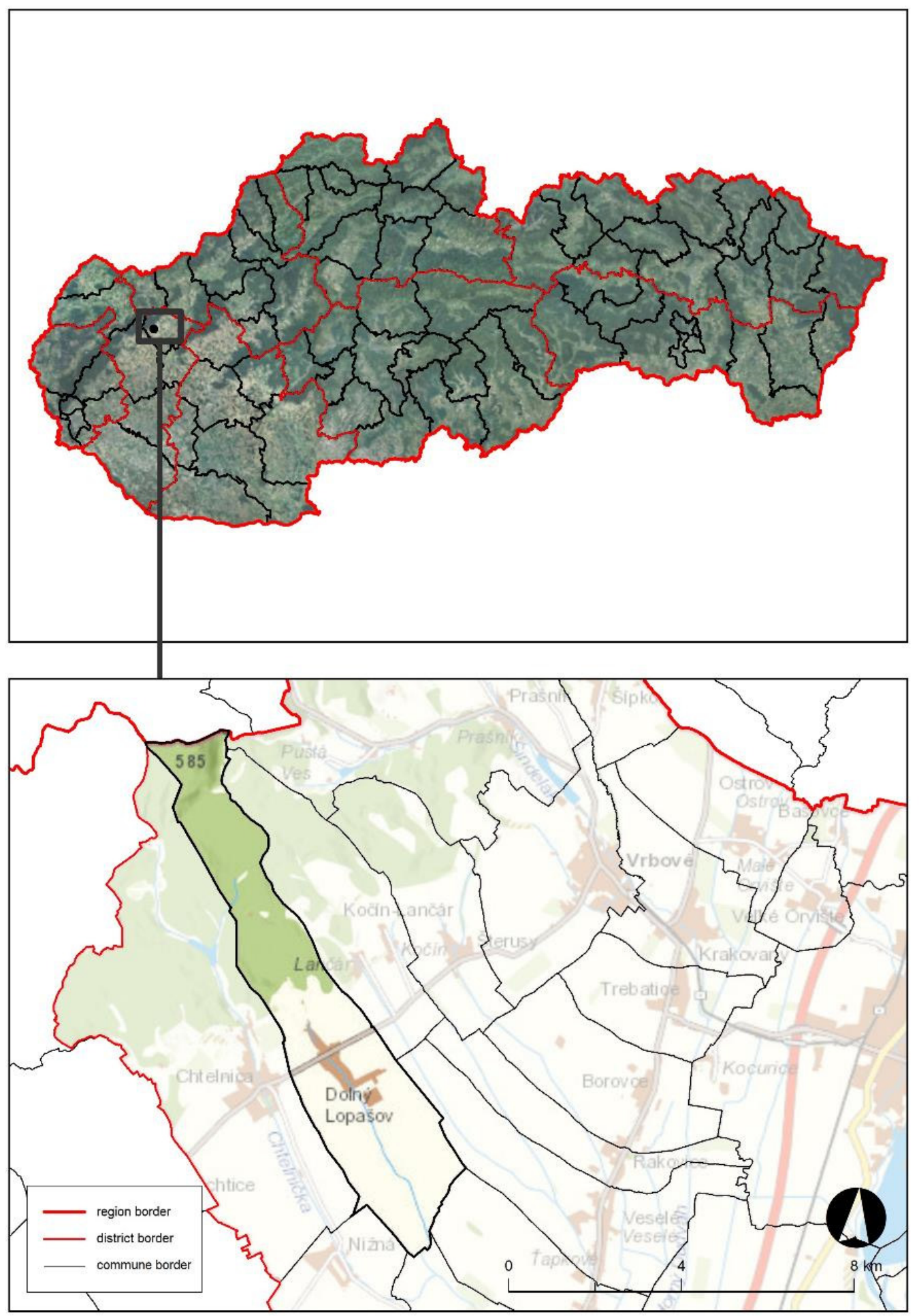

Figure 1. Dolný Lopašov community location. Technical processing: Rákayová, R.

The current community cadastral territory is 2293.41 ha (Figures 2 and 3). 


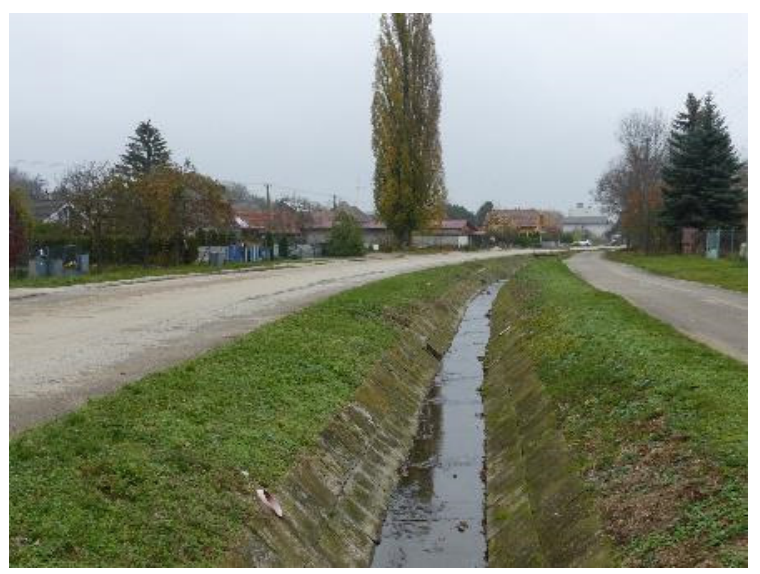

Figure 2. Dolný Lopašov community (Moyzeová, 2020).

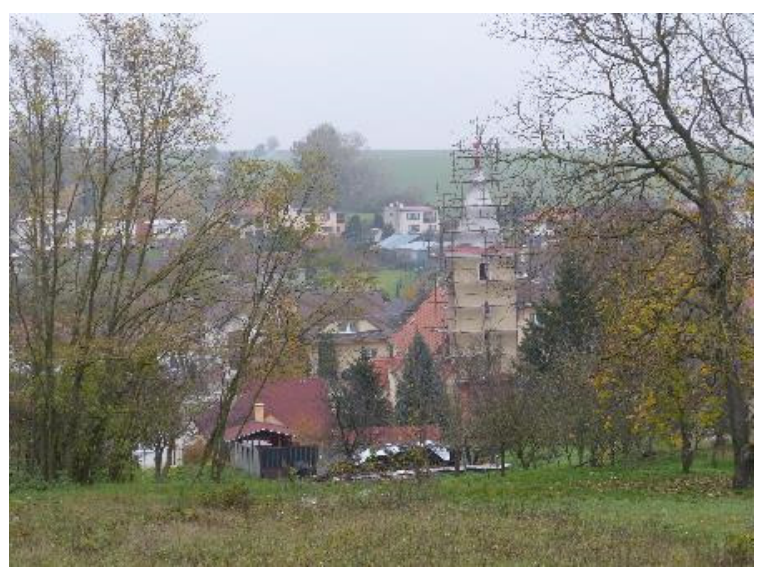

Figure 3. Dolný Lopašov community (Moyzeová, 2020).

The community centre $\left(48^{\circ} 34^{\prime} 37^{\prime \prime}, 17^{\circ} 38^{\prime} 35^{\prime \prime}\right)$, however, is at $207 \mathrm{~m}$ a.s.l., and the Malé Karpaty Mountains/Trnavská pahorkatina Hill Land border runs along the $250 \mathrm{~m}$ contour line (Špulerová et al., 2020) [23]. According to data from the Statistical Office in 2020, 982 inhabitants lived in the commune, and Mazúr and Lukniš (1986) [26] record the following study area geomorphological divisions: the Podunajská pahorkatina hill land units and the Malé Karpaty Mouintain subunits; the Trnavská pahorkatina hills and the Brezovské Karpaty Mountains and parts thereof. The Podmalokarpatská pahorkatina hill land then forms the Trnavská Tabul'a. This table is dominated by Quaternary rocks with the presence of terrace aluminous gravel sediments and loess clays. The Podmalokarpatská pahorkatina hill land has Neogene aluminous to stony-aluminous weathering on karstic limestones and the Brezovské Karpaty Mountains contain limestones and dolomites. In terms of inclination, a slight inclination from $1-7^{\circ}$ predominates the terrain, this then increases up to $3^{\circ}$ in the hill landscape, $7-12^{\circ}$ towards the mountains and finally $17-25^{\circ}$ is the steepest inclination on the eastern slopes of Klenová hill.

The communal territory lies in the river Váh watershed with the $7.9 \mathrm{~km}$ Lopašov River flowing through the studied territory. Figure 4 shows the modified watercourse in the builtup areas, and Figure 5 highlights the natural river flow through the Trnavská tabul'a fertile and agriculturally intensive landscape (Špulerová et al., 2020) [23]. Finally, the community lies in the following three hydrogeological regions: (1) the Trnavská pahorkatina hill land Quaternary and Neogene, and (2) the Mesozoic of the northern part of the Pezinské and Brezovské Karpaty Mountains (Malík, Švasta 2002) [27]. 


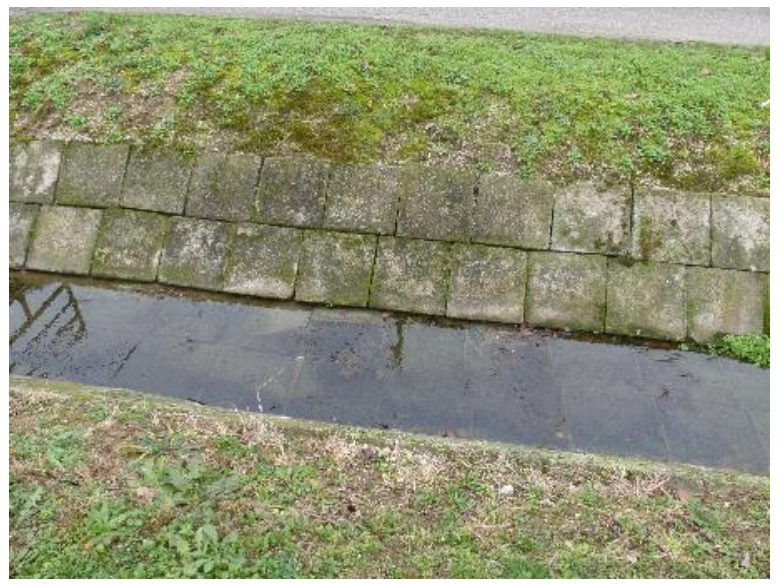

Figure 4. Lopašov Flow—modified watercourse (Moyzeová, 2020).

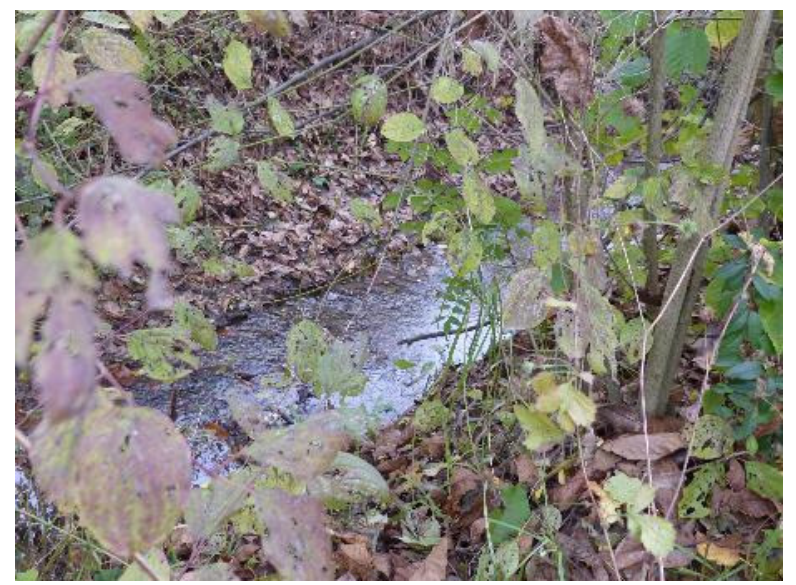

Figure 5. Lopašov flow—natural flow (Moyzeová, 2020).

\subsection{Soil, Climate and Biota}

The greatest percentage of communal soil types are $42.06 \%$ haplic luvisols and $24.85 \%$ rendzics. The hill land has high-quality haplic with predominantly bonita soil, while low quality rendzics predominately in the upland Malé Karpaty Mountain Forest ecosystems. In addition, the Lopašov valley has fertile mollic fluvisols, and $80 \%$ is clay-loam mediumheavy soil. There are also moderately deep forest soils, and deeper soils in intensive agricultural areas.

The Dolný Lopašov area has both a mountain and lowland climate. This varies from moderately warm to warm, and it enables growth of seven natural vegetation communities. The highest at $65.3 \%$ is Carici pilosae-Carpinenion betuli oak-hornbeam forest, followed by $14.74 \%$ Quercetum petraeae-cerris thermophilous and supra-Mediterranean oak woods, $6.78 \%$ Cephalanthero-Fagenion limestone beech forests, $5.17 \%$ woods in the mountains and mountain foothills (Alnenion glutinoso-incanae, Salicion triandrae, Salicion eleagni), 2.19\% Neutrophilous beech forests (Eu-Fagenion) and the lowest at $0.2 \%$ is Thermophilous and supra-Mediterranean oak woods (Potentillo albae-Quercion. Figure 6 depicts the community landscape elements. These are dominated by agricultural crops which occupy $53.41 \%$ of the area. Figure 7 then shows the scrub and tree vegetation at $40.32 \%$. 


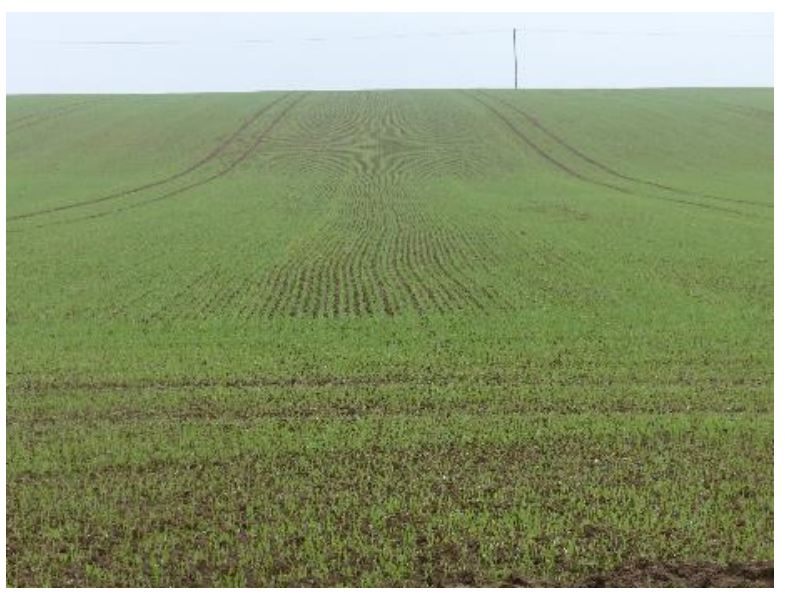

Figure 6. Large-block arable land (Moyzeová, 2020).

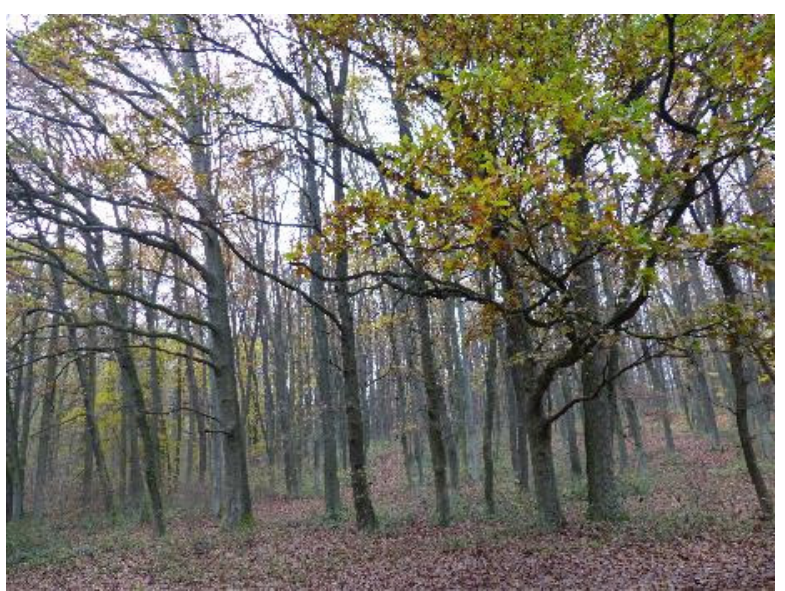

Figure 7. Tree vegetation (Moyzeová, 2020).

While urban, built-up and industrial areas occupy $4.28 \%$ of the communal territory, the lowest at $1.49 \%$ consists of grasslands and outcrops, and the remaining $0.5 \%$ is sub-soil and bare soils. The diverse landscape structure in Dolný Lopašov is characterized by a landscape structure which provides favourable habitats for both vertebrates and invertebrates, and especially for the species-rich Coleoptera beetles and plentiful butterfly species in the Little Carpathian foothills (Malé Karpaty). Špulerová et al. (2020) [23] identified mammals in the study area, and there are also amphibians and reptiles. The presence of common and rare bird species is due to the majority of the communal area being in the protected bird areas of the Malé Karpaty Mountains and Špačiansko-nižnianske pasture land.

\subsection{Industrial Effects}

There are no communal industries with significant negative effects on the environmentonly small craft operations such as carpentry and repair shops. However, the eastern edge of the Malé Karpaty Protected Landscape Area (PLA) has a quarry with environmental impacts of noise and dust. This combines with the network of overhead lines and wiring which cause electromagnetic disturbance and consequent barriers to local birds and bats. Underground lines further negatively affect soil distribution and consequently soil biota ecology. Finally, the Dolný Lopašov agricultural cooperative for plant and animal production in the southeastern part of the area produces cattle-breeding odour and increased dust and noise during harvest periods. This is in addition to the potential water and soil pollution from mechanization, fertilizers and excrement storage. 


\subsection{Transport and Facilities}

The main Dolný Lopašov transport corridor is the second-class road heading towards Smolenice, Vrbove and the Bratislavan national capital. This is complemented by local roads; and all of these form spatial barriers to biota migration. In addition, they also burden the environment with associated noise, dust and lighting ill-effects, and road repair, traffic fumes and dust from chemical applications during snow-bound winters all further influence air, soil and water quality.

These, however, are compensated by the following communal facilities and benefits: population size and friendliness; settled residential buildings; the presence of most civil amenities, including its municipal office, two medical centres, a fire station, post office, kindergarten and primary school, a cultural setting with a library and hall for folk activities ('dom kultury'), two retail stores for food and necessary purchases, and appropriate sites for sport, recreation and leisure. All built-up areas are barriers to animal migration (Špulerová et al., 2020) [23].

Table 1 lists the relatively high proportion of positive community socio-economic factors. Our research into these factors centres on the territory's combined published information, legislative regulations and published scientific research.

Table 1. (a-h) lists the Dolný Lopašov positive socio-economic elements.

a: Elements of nature and landscape protection.

\begin{tabular}{|c|c|c|c|}
\hline $\begin{array}{c}\text { Category of Protected Area } \\
\text { (PA) }\end{array}$ & Name & Legislative & Area in DL (Area PA) in ha \\
\hline $\begin{array}{l}\text { Protected Landscape Area } \\
\text { (PLA); 2nd degree } \\
\text { of protection }\end{array}$ & PLA Malé Karpaty & $\begin{array}{l}\text { Act No. } 543 / 2002 \text { Coll. Nature and } \\
\text { landscape protection } \S 18, \\
\S 13 \text {-degree of protection }\end{array}$ & $\begin{array}{c}944.92 \text { ha } \\
(70,632.91 \text { ha })\end{array}$ \\
\hline \multirow{2}{*}{$\begin{array}{l}\text { Natural Reservations (NR) } \\
\text { 5th degree of protection }\end{array}$} & NR Lančársky Dubník & $\begin{array}{l}\text { Act No. } 543 / 2002 \text { Coll. Nature and } \\
\text { landscape protection } \S 22, \\
\S 15-16 \text { - degree of protection }\end{array}$ & $\begin{array}{l}9.07 \mathrm{ha} \\
\text { (26.71 ha) }\end{array}$ \\
\hline & NR Pod Holým vrchom & $\begin{array}{c}\text { Act No. } 543 / 2002 \text { Coll. Nature and } \\
\text { landscape protection } \S 22, \\
\S 15-16 \text { - degree of protection }\end{array}$ & 12.63 ha (12.63 ha) \\
\hline
\end{tabular}

b: NATURA 2000.

\begin{tabular}{|c|c|c|c|}
\hline Category & Name & Legislative & Area in DL (Area PA) in ha \\
\hline $\begin{array}{l}\text { Special areas of conservation } \\
\text { (SCI) Sites of Community } \\
\text { Importance }\end{array}$ & $\begin{array}{l}\text { SKUEV0278 Brezovské } \\
\text { Karpaty }\end{array}$ & $\begin{array}{l}\text { Decree of the Ministry of the } \\
\text { Environment (ME) of the Slovak } \\
\text { Republic (SR) No.3/2004-5.1, which } \\
\text { issues a national list of territories of } \\
\text { European importance } \\
\text { Measure of the Ministry ME SR No. } \\
1 / 2017 \text { which amends the Decree of } \\
\text { the ME of the SR No. 3/2004-5.1 } \\
\text { which issues a national list of } \\
\text { territories of European importance }\end{array}$ & $\begin{array}{c}51.72 \text { ha } \\
(2670.95 \text { ha })\end{array}$ \\
\hline \multirow{2}{*}{$\begin{array}{l}\text { Special protection areas (PBA) } \\
\text { Protected Bird Area }\end{array}$} & $\begin{array}{l}\text { SKCHVÚ014 Malé } \\
\text { Karpaty }\end{array}$ & $\begin{array}{l}\text { Decree of the ME SR No. 216/2005 } \\
\text { Coll., declaring The Malé Karpaty } \\
\text { PLA }\end{array}$ & $\begin{array}{c}944 \text { ha } \\
(52,458.48 \text { ha })\end{array}$ \\
\hline & $\begin{array}{c}\text { SKCHVÚ054 } \\
\text { Špačinsko-nižnianske } \\
\text { polia }\end{array}$ & $\begin{array}{c}\text { Decree of the ME SR No. 27/2011 } \\
\text { Coll. Declaring the PBA } \\
\text { Špačinsko-nižnianske polia }\end{array}$ & $\begin{array}{c}697 \text { ha } \\
(12,155.66 \text { ha })\end{array}$ \\
\hline
\end{tabular}


Table 1. Cont.

c: Elements of the territorial system of ecological stability (TSES).

\begin{tabular}{|c|c|c|c|}
\hline Category & Name & Legislative & Characteristic \\
\hline & $\begin{array}{l}\text { SBc Hrebeňový systém } \\
\text { Malých Karpát }\end{array}$ & $\begin{array}{l}\text { Act No. } 543 / 2002 \text { Coll. } \\
\text { Nature and landscape } \\
\text { protection } \S 2\end{array}$ & $\begin{array}{l}\text { Forest communities of the } \\
\text { Malé Karpaty Mountains }\end{array}$ \\
\hline Supra-regional biocorridor & $\begin{array}{l}\text { SBc Biokoridor podhoria } \\
\text { Malých Karpát }\end{array}$ & $\begin{array}{c}\text { Act No. 543/2002 Coll. } \\
\text { Nature and landscape } \\
\text { protection } \S 2 \\
\text { Act of the National Council SR } \\
\text { No. } 237 / 2000 \text { Coll. } \\
\text { Act of the Slovak National } \\
\text { Council No. 330/1991 Coll. } \\
\text { Resolution of the Government } \\
\text { SR No. 319/1992 Coll. }\end{array}$ & $\begin{array}{l}\text { Biocorridor passes through } \\
\text { the edge of the Male Karpaty } \\
\text { Mountains in the contact with } \\
\text { the deforested hilly landscape }\end{array}$ \\
\hline Regional biocorridor & RBc Lopašovský potok & $\begin{array}{c}\text { Act No. } 543 / 2002 \text { Coll. } \\
\text { Nature and landscape } \\
\text { protection } \S 2 \\
\text { Act of the National Council SR } \\
\text { No. } 237 / 2000 \text { Coll. } \\
\text { Act of the Slovak National } \\
\text { Council No. } 330 / 1991 \text { Coll. }\end{array}$ & $\begin{array}{c}\text { Biocorridor is formes by thje } \\
\text { Lopašov flow and its adjacent } \\
\text { butterbur river in } \\
\text { communities which are } \\
\text { interrupted by buildings }\end{array}$ \\
\hline \multirow[t]{2}{*}{ Regional biocentre } & $\begin{array}{l}\text { RB Lančársky Dubník } \\
\text { RB Pod Holým vrchom }\end{array}$ & \multirow{2}{*}{$\begin{array}{l}\text { Act No. } 543 / 2002 \text { Coll. } \\
\text { Nature and landscape } \\
\text { protection } \S 22,\end{array}$} & $\begin{array}{l}\text { NR with dense perennial } \\
\text { grasslands in the } \\
\text { Podmalokarpatská } \\
\text { pahorkatina Hill Land }\end{array}$ \\
\hline & $\begin{array}{l}\text { RB Skaly nad Dolným } \\
\text { Lopašovom }\end{array}$ & & $\begin{array}{c}\text { Rock communities and dense } \\
\text { perennial grasslands on a } \\
\text { former quarry }\end{array}$ \\
\hline \multirow{4}{*}{ Local biocentre } & LB Nad obcou & \multirow{4}{*}{$\begin{array}{c}\text { Act No. } 543 / 2002 \text { Coll. } \\
\text { Nature and landscape } \\
\text { protection } \S 2 \\
\text { Act of the National Council SR } \\
\text { No. } 237 / 2000 \text { Coll. } \\
\text { Act of the Slovak National } \\
\text { Council No. } 330 / 1991 \text { Coll. }\end{array}$} & $\begin{array}{l}\text { It is designed on the site of a } \\
\text { forest on the north-western } \\
\text { edge of the commune }\end{array}$ \\
\hline & LB Nad cintorínom & & $\begin{array}{l}\text { This is a proposal to create a } \\
\text { new biocentre on arable land } \\
\text { above the cemetery, following } \\
\text { the local biocorridor Pahorky }\end{array}$ \\
\hline & LB Trstina od Dubovianskeho & & $\begin{array}{l}\text { The biocentre consists of a } \\
\text { small forest on arable land }\end{array}$ \\
\hline & LB Pri družstve & & $\begin{array}{c}\text { Design of local biocentre } \\
\text { versus a cooperative, tree } \\
\text { communities and floodplain } \\
\text { forest draw }\end{array}$ \\
\hline
\end{tabular}

Act No. 543/2002 Coll. Nature and landscape protection $\S 2$

Local biocorridor $\quad$ LBc Pahorky
Act of the National Council SR

No. 237/2000 Coll.

Act of the Slovak National

Council No. 330/1991 Coll.
The terrestrial biocorridor is formed by a belt of non-forest woody vegetation around the access road to the quarry 
Table 1. Cont.

\begin{tabular}{|c|c|c|}
\hline & d: Elements of protection of water resources. & \\
\hline Category & Name & Legislative \\
\hline \multirow[b]{2}{*}{$\begin{array}{l}\text { Protective zone of water } \\
\text { supply-1st degree } \\
\text { of protection }\end{array}$} & $\begin{array}{c}\text { Dolný Lopašov—lokalita Mlynársky (area-179.3 ha; area in the } \\
\text { commune-173.9 ha) }\end{array}$ & OPLVH/39/116/85 \\
\hline & $\begin{array}{l}\text { Prašník, Košariská—Pod Javorom, HPF-1, 2, 3, 4a, Fajnory, Mlyn } \\
\text { 1-4, Stanovisko, Chrenkech jarok, Mosnáci, Lopušná dolina } \\
\text { (area-2914.43 ha; area in the commune-101.21 ha) }\end{array}$ & $\begin{array}{c}\text { OPLVH-SE1559/88/807/89- } \\
\text { 6/24/140, OPLVH } \\
\text { No.1559/88/807/89- } \\
0.001785714 \\
\text { ŠVS/2000/01114-Me }\end{array}$ \\
\hline Vulnerable areas & $\begin{array}{l}\text { The commune Dolný Lopašov (area-1233.77 ha; area in the } \\
\qquad \text { commune-1231.74 ha) }\end{array}$ & $\begin{array}{l}\text { Act No. } 364 / 2004 \text { Coll. On } \\
\text { waters } \$ 34 \\
\text { Government } \\
\text { Regulation } 617 / 2004 \text { Coll. }\end{array}$ \\
\hline $\begin{array}{l}\text { Water management of } \\
\text { significant water flow }\end{array}$ & Lopašov flow & $\begin{array}{l}\text { Act No. } 364 / 2004 \text { Coll. On } \\
\text { waters } \S 44 \\
\text { Decree } 211 / 2005 \text { Coll. }\end{array}$ \\
\hline
\end{tabular}

e: Elements of protection of soil resources.

\begin{tabular}{|c|c|c|c|}
\hline \multicolumn{2}{|c|}{ Category } & Area & $\begin{array}{l}\% \text { of Area Agricultural Fund } \\
\text { in the Commune }\end{array}$ \\
\hline \multicolumn{2}{|c|}{ 1st class BSEU (Bonited Soil-Ecological Units) } & 2.83 & 0.12 \\
\hline \multicolumn{2}{|c|}{ 2nd class BSEU } & 9.65 & 0.42 \\
\hline \multicolumn{2}{|c|}{ 3rd class BSEU } & 849.2 & 37.05 \\
\hline \multicolumn{2}{|c|}{ Investment to land (land reclamation, irrigation) } & $\begin{array}{l}\text { Drained areas } 92.81 \text { ha } \\
\text { Irrigation } 390.33 \text { ha }\end{array}$ & $\begin{array}{c}4.04 \\
17.03\end{array}$ \\
\hline \multicolumn{4}{|c|}{ f: Elements of protection of mineral resources. } \\
\hline Category & Name & Area & Characteristic \\
\hline $\begin{array}{l}\text { Protected area of deposits } \\
\text { with reserved minerals }\end{array}$ & $\begin{array}{c}\text { Dolný Lopašov (license plate } \\
\text { No. 020/a) }\end{array}$ & $75,112 \mathrm{~m}^{2}$ & Dolomites—dolomitic sands \\
\hline $\begin{array}{l}\text { Protected area of deposits } \\
\text { with non-reserved minerals }\end{array}$ & Dolný Lopašov & $75,112 \mathrm{~m}^{2}$ & Dolomites-dolomitic sands \\
\hline Mining area & $\begin{array}{l}\text { Dolný Lopašov (license plate } \\
\text { No. 055/A) }\end{array}$ & $75,112 \mathrm{~m}^{2}$ & Dolomites-dolomitic sands \\
\hline \multicolumn{4}{|c|}{ g: Elements of protection of cultural and historical resources. } \\
\hline Category & Name & \multicolumn{2}{|c|}{ Legislative } \\
\hline $\begin{array}{l}\text { Immovable national cultural } \\
\text { monuments }\end{array}$ & $\begin{array}{l}\text { Church with grounds (St. } \\
\text { Martina) } 821 / 10\end{array}$ & \multicolumn{2}{|c|}{$\begin{array}{l}\text { Act No. 49/2002 Coll. On the protection of the monument } \\
\text { fund } \S 2\end{array}$} \\
\hline \multicolumn{4}{|c|}{ h: Elements of protection of forests resources. } \\
\hline Category & Subcategory & Area in ha & $\begin{array}{l}\text { \% Representation of the } \\
\text { Forest Category in the } \\
\text { Commune }\end{array}$ \\
\hline A & $\begin{array}{l}\text { Protective forests-forests in } \\
\text { exceptionally unfavourable } \\
\text { places }\end{array}$ & 184.70 & 21.24 \\
\hline $\mathrm{D}$ & $\begin{array}{l}\text { Protective forests-other } \\
\text { forests with predominant } \\
\text { protection of soil }\end{array}$ & 40.77 & 4.69 \\
\hline
\end{tabular}

\subsection{Evaluation of Positive Socio-Economic Phenomena}

We evaluated positive socio-economic phenomena according to the new methodology for the development projects of TSES at the local level (Miklós et al., 2020) [28]. The methodology has not yet been adopted by legislation. The basis of the methodological 
procedure is the LANDEP methodology developed at the Institute of Landscape Ecology of Slovak (Ružička, Miklós, 1982) [29].

To determine the landscape ecological significance of PSEP, we based it on:

1. Analysis enabled the creation of the basic indicators of landscape characteristics. These indicators are essential in TSES creation. Here, we focused on identifying positive socio-economic factors which support communal ecological stability. This particularly involved analysis of the legal status for protection of the community's nature and natural resources. These results provide specification of the methods used in spatial expression and the following legislative protection: the protection of nature and landscape and forest, mineral, water, soil and cultural and historical resources. The mapped Dolný Lopašov communal elements are highlighted in Figure 8 showing positive socio-economic factors (PSEF).

2. Syntheses require processing the basic synthetic maps. These are created by multiple super-impositions of analytic maps on parts of the synthetic maps. This required spatial synthesis of the positive elements which determine the actual TSES status. Finally, the synthesis includes the territorial system of positive elements, and the complex communal PSEF model is expressed in the following codes.

$\mathrm{PSEF}=\left(\mathrm{X}_{1}, \mathrm{X}_{2}, \mathrm{X}_{3}, \ldots \ldots \ldots \ldots \ldots \ldots \ldots \mathrm{X}_{14}\right)$ code comprises:

$\mathrm{X}_{1}$-PLA (protected landscape area)

$\mathrm{X}_{2}-\mathrm{NR}$ (nature reserve)

$\mathrm{X}_{3}-\mathrm{B}$ (biocentre)

$\mathrm{X}_{4}-\mathrm{Bc}$ (biocorridor)

$\mathrm{X}_{5}$-GL (gene pool locality)

$\mathrm{X}_{6}$ - PBA (protected birds area)

$\mathrm{X}_{7}$-SCI (sites of community importance)

$\mathrm{X}_{8}-\mathrm{PF}$ (protective forests)

$\mathrm{X}_{9}-\mathrm{PZ}$ WS (protective zone of water supply)

$\mathrm{X}_{10}$-WMSWF (Water management significant water flow)

$\mathrm{X}_{11}$-the best quality according to BSEU

$\mathrm{X}_{12}$-investment land

$\mathrm{X}_{13}$-PAD (protected area of deposits)

$\mathrm{X}_{14}$-INCM (immovable national cultural monuments)

The result of the syntheses is a synthetic map, which is best expressed in terms of parametric synthesis, i. j., in the form of codes. The model for creating a synthetic map is as follows:

$$
S=\left(X_{1}, X_{2}, X_{3}, \ldots X_{n}\right),
$$

where $\mathrm{S}=$ type of synthesis, $\mathrm{X} \mathrm{i}=$ type of properties of individual components that entered the synthesis, $\mathrm{n}=$ number of components that entered the evaluation.

3. Landscape ecological interpretation is the final step in our TSES method. The goal is the precise re-assessment of the actual measurable and objectively evaluated properties of positive socio-economic indicators. The results then provide suitable criteria for the preservation, modification or design of new TSES elements, eco-stability and landscape ecological significance. This determines a hierarchy of the ecological value of elements in the landscape structure. Herein, we established the Dolný Lopašov level of significance with the following:

(1) Legislatively defined areas of nature and landscape protection. This comprises the PLA Malé Karpaty, NR Lančársky Dubník, NR Pod Holým vrchom, PBA Špačinskonižnianske polia, PBA Malé Karpaty, SCI Brezovské Karpaty.

(2) TSES elements: These include the supra-regional biocorridor terrain, the regional biocentre Lančársky Dubník and the regional biocentre Pod Holým vrchom, a regional biocorridor Lopašov flow. Many of these TSES elements are linked to protected areas, including forest resource sites.

(3) Protected natural and cultural-historical resource elements and other eco-stabilizing elements. This group comprises non-forest woody vegetation, with isolated woods 
and groups of woody plants. These include the protected water supply zones, especially those that ensure water management and significant Lopašov flow. In addition, there are the "BSEU best quality" protected forest and soil resources, protected mineral deposits and cultural historical resources. A perfect example of this latter protection is the St. Martin's Church national cultural protected monument.

(4) Other eco-stabilizing elements. This group comprises non-forest woody vegetation, with isolated woods and groups of woody plants. These include a predominance of trees, woody vegetation and scrubs which have great landscape ecological importance in this agriculturally intensive area.

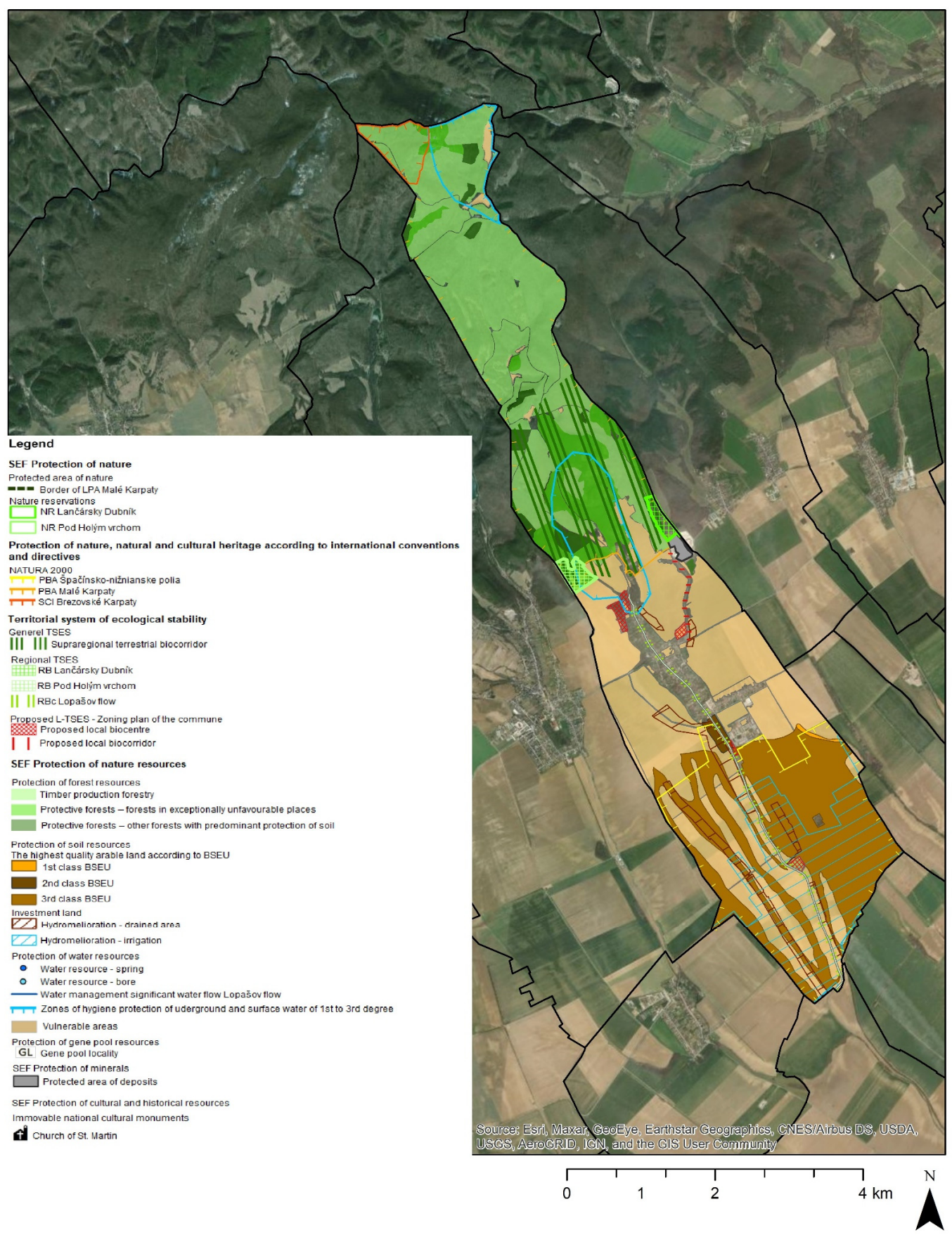

Figure 8. Positive socio-economic factors of Dolný Lopašov community. Author: Moyzeová, M. Technical processing: Raniak, A. (in Špulerová, et al., 2020). 
We carried out the final evaluation of PSEP using the method of expert estimation on the basis of an empirical evaluation of real-occurring combinations of PSEP. We obtained a part of the input information from the database of socio-complex parameters, synthetically processed in the synthesis part. We obtained additional data from literary sources, the archive, departmental databases, legislative regulations and methods of structured observations of phenomena in a certain category of protection.

\section{Results-Evaluation of Landscape Ecological Significance}

In the cadastral area of the village of Dolný Lopašov, we have specified eight categories of landscape ecological significance based on the occurrence, abundance and combination of PSEP.

In the first category of importance, we have included the area of a dual combination of nature protection and protection of natural resources-forest, water and mineral resources. There are nine positive phenomena in the area in the second to fifth level of protection: PLA, a nature reserve, a biocentre, a biocorridor, protective forests, water resource protection zones, gene pool locality, a protected bird area and a protected deposit area.

In the second category of significance, we included the area of the dual combination of nature protection and protection of natural resources-forest and water, with the representation of five PSEP: PLA, a biocorridor, protective forests, water protection zones and a protected bird area.

In the third category of significance, we include the area with a combination of nature protection and forest resource protection, with the representation of three PSEP: PLAs, protective forests and the protected bird area of the Špačinsko-Nižnianske fields.

In the fourth category of importance, we included the area with a dominant protection of soil resources. It is a southern part of the cadastral area in which there is land with high production capacity that is intensively used by agriculture. In addition to the protection of soil resources, the area also includes elements of water protection and nature protection in a combination of five PSEP: the highest quality land, investment land, a protected bird area in combination with the line elements of a biocorridor and water management significant watercourse.

In the fifth category of importance, we included the area with dominant protection of soil resources, with the occurrence of four PSEP: the best soil, a protected bird area, water management important watercourse and a biocorridor.

We have included an area with a combination of three elements in the sixth category of knowledge: the highest quality land, investment-friendly land and a protected bird area. In this part of the area, in addition to large arable land, there are also planar and linear elements of vegetation, which are important in terms of ecological stability and biodiversity, as these are bird habitats that are subject to the protection of the protected bird area.

We have included the area with the lowest proportion of PSEP in the seventh category of significance. The area is located in the central part of the cadastral area and consists mainly of the built-up area where there are two elements of PSEP: an immovable national cultural monument-St. Martin's Church—and water management significant watercourse Lopašovský stream.

We include the area with the monofunctional protection of soil resources in the eighth category of significance. It consists of large block soils located in the vicinity of the built-up area of the village, which are intensively cultivated and have a low proportion of area and line vegetation.

Landscape ecological significance is expressed in Figure 9. 


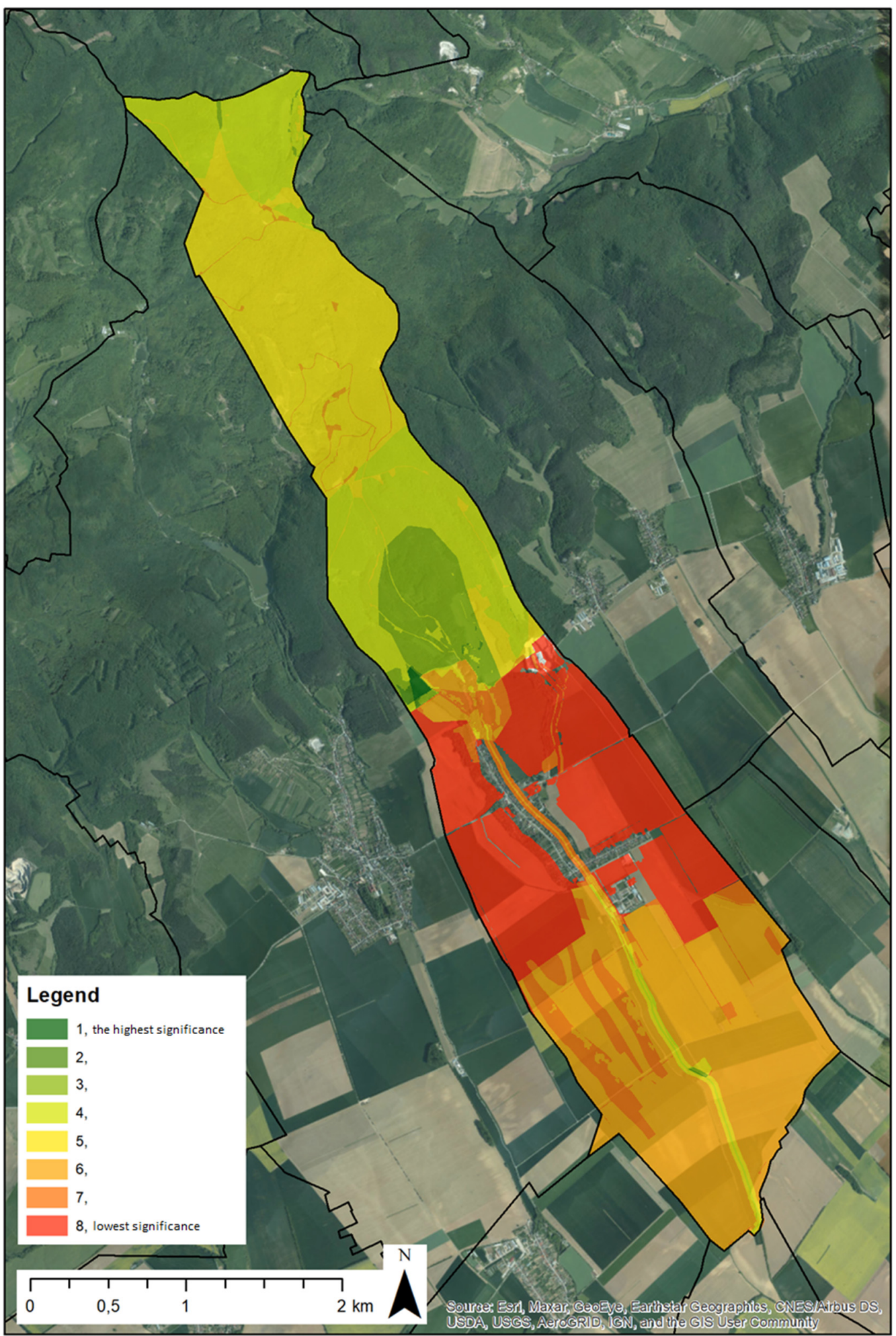

Figure 9. Landscape ecological significance. Author: Moyzeová, M. Technical processing: Rákayová, R.

\section{Discussion and Conclusions}

The process of land classification on the basis of landscape ecological significance is one of the key parts of the processing of TSES documents. The aim of the classification is to set aside areas with approximately the same degree of ecological stability of the landscape, which in turn makes it possible to determine the hierarchy of protection and land use needs (Jančura et al., 1994) [30]. For this purpose, stability should be understood as a 
country's ability to cope with disruptive influences without permanently disrupting its functional mechanisms (Löw, 1984) [31]. Such an assessment is carried out, for example, on the basis of a reassessment of only real vegetation or the current landscape structure. Another more complex method, based on the comparison of natural conditions and the way land is used, is presented in the works of Tremboš, et al. (1997) [32] and Minár, Tremboš (1995) [33]. The approaches of Slovak landscape ecologists Ružička, Hrnčiarová (1995) [34], Hrnčiarová, Izakovičová (2000) [35], Miklós, Izakovičová (1997) [36], Miklós (1996, 2010) [7,37], Izakovičová et al. (2000, 2011) [38,39] and Izakovičová, Moyzeová (2002) [40] are based on an assessment of the landscape's features that support, protect but also reduce its ecological stability. In this case, data on various types of protected areas are included in the assessment together with information on the current landscape structure and elements of the territorial system of stress factors. Within the methodological procedures for the processing of TSES projects, it is therefore important to classify the territory on the basis of the syntheses of the above indicators, including the syntheses of PSEP that support stability and form a territorial system of PSEP in the territory. We interpret landscape ecological significance from analytical and synthetic sources, while the degrees of significance of biota elements, the current landscape structure and significant landscape elements are determined from a landscape ecological and biological point of view. Such an assessment is also presented by the newly proposed methodology of processing local ecological stability systems (Miklós et al., 2020) [24], which was also used in the design of the local territorial system of ecological stability of the commune Dolný Lopašov. The categorization process based on positive socio-economic elements divided the cadastral territory of the commune Dolný Lopašov into different parts. The northern part has the largest share of natural elements in the whole area. The area has a predominance of natural and nature-friendly forests and is characterized by a high degree of ecological stability and biodiversity. Many of these elements represent nature protection areas, elements of the territorial system of ecological stability, habitats of European and national importance, i.e., sites important in terms of conservation and the development of the gene pool. The area is characterized not only by high forest management but also water management potential. The southern part of the cadastral area was evaluated in terms of the representation of PSEP as an area of medium landscape ecological significance. The dominant element in the landscape structure is arable land, high production capacity, intensively agriculturally used land with a low proportion of area and line vegetation. Local agroecosystems have a low degree of ecological stability. The lowest part of the cadastral area has the lowest landscape ecological significance, which consists of built-up, unstable urban areas together with local roads, which act as barriers for animal migration and are of minimal importance for the biota of the natural landscape. These elements are complemented by large-scale arable land of lower production capacity located in the vicinity of the village. The evaluation of PSEP is therefore very important as it enters the overall classification of the territory, which we achieve by synthesizing partial classifications-abiotic complexes, stress factors and current landscape structure with a focus on biotic elements and PSEP.

We agree with the opinion of Buček (2013) [2] that a cultural landscape cannot be harmonious without the permanent provision of biodiversity, geodiversity and ecological stability. Less ecologically stable and unstable ecosystems characterized by a reduction in ecological stability and limited biodiversity have prevailed, and they predominate and will continue to predominate in the cultural landscape. Areas of these often deliberately destabilized ecosystems must therefore be balanced and subdivided by suitably distributed areas of ecologically more stable natural and close to nature ecosystems, the system of which forms an ecological network in the country (Buček, 2013) [2]. As a spatial landscape formation this network includes places with suitable habitats for the permanent existence of species as well as areas and line formations that allow its functional interconnection (Anděl, 2013) [41]. At the same time, the care of the ecological network undoubtedly meets the requirements of the European Landscape Convention aimed at preserving the landscape heritage and identity of each cultural landscape (Buček, 2013) [7]. 
The current extension and approval of the territorial systems of ecological stability (TSES) are the most important because the existing and newly proposed elements will be essential components of an optimally balanced national ecology network.

The aim of TSES is to preserve and support the development of the natural gene pool of the landscape, and the preservation and supplementation of stabilizing elements in the country, ensuring their favourable effect on the surrounding ecologically and less stable parts of the landscape, and supporting the possibility of multifunctional land use, significant landscape elements and the elimination of stress factors that threaten individual positive elements (KURS, 2001) [42].

The local TSES project of the Dolný Lopašov village is a document of nature and landscape protection, the aim of which is to create conditions to increase the biodiversity of the landscape at the local level and to support the regulation of the use of natural resources in a sustainable way. The methodological procedure used in the processing of the local TSES of the municipality of Dolný Lopašov was based on the methodology for the automated generation of local TSES documents (Miklós et al., 2020) [24] which was developed for the need of creating a support system for processing local TSES. The methodology is based on the parameterization and georeferencing of information on the properties of primary, secondary and tertiary landscape structures in the GIS environment and builds on all existing methodologies and methodological guidelines of the Ministry of the Environment (1993) [43], the manual on the methodology of TSES (Jančura et al., 1994) [30], methodical instructions for the elaboration of regional TSES documents (Štefek, Múdry, 1993 [44], Bohálová (ed.), 2014 [45]), methods of classification of the ecological stability of an area (Ružička, Hrnčiarová, 1995) [34], the Draft Instruction of the Ministry of the Environment of the Slovak Republic for the elaboration of projects of regional and local territorial systems of ecological stability (Kol., 1999) [46], methodical guidelines for the elaboration of regional TSES and local TSES projects (Izakovičová et al., 2000) [38], methodical instructions for the elaboration of the local TSES (Pauditšová et al., 2007) [47] and also to the Decree of the Ministry of the Environment of the Slovak Republic no. 24/2003 Coll. [48], which implements Act no. 543/2002 Coll. on nature and landscape protection, Decree no. 492/2006 Coll. [49], amending the Decree of the Ministry of the Environment of the Slovak Republic no 24/2003 Coll., which implements Act no. 543/2002 Coll. on nature and landscape protection as well as other theoretical and methodological works by Ružička, Miklós (1982) [29], Miklós (1996, 2010) [7,37], Miklós et al. (2011) [50], Miklós, Izakovičová $(1997,2013)$ [36,51], Petrovič (2007) [52], Izakovičová, Moyzeová (2002) [40], Moyzeová (ed.) (2015) [53], Jurko (1990) [54], Odum (1975) [55], Nowicki et al. (1996) [56] and Miklós et al. (2020) [28], in which PSEP also enter into the assessment of ecological stability. In addition, knowledge of positive elements in an area and their combinations will improve both the proposed TSES elaboration and eco-stabilizing measures. This is necessary because those measures are limiting factors for the proposed activities, and they provide information on the nature and landscape protection area for the important TSES framework design and legislative protection. Here, it was essential to research landscape ecological significance at the local level, because agricultural land in Dolný Lopašov is intensively cultivated.

Commune Dolný Lopašov was selected as the model for the verification of the new concepts contained in the processing documents for local ecological stability systems. Finally, landscape ecological significance was assessed, and this provided the foundation for regulating the green infrastructure design developed in cooperation with ILE SAS and Esprit.

From the results of the assessment of landscape ecological significance, we can conclude that the degree of ecological stability can be determined only relatively, provided that it is inversely proportional to the intensity of the anthropogenic impact on the ecosystem. The assessment of landscape ecological significance determines the degree of naturalness and the dynamics of natural processes in the ecosystem for preserving and maintaining conditions for regeneration and renewal of the gene pool, natural resources, ecological stability, biodiversity, the preservation of rare cultural and historical elements and fulfill- 
ment of other utility and ecological functions in the country, soil protection, microclimate and health-including hygienic, aesthetic, therapeutic, cognitive, etc. (Izakovičová et al., 2000) [38].

From the results of the evaluation of PSEP in the commune Dolný Lopašov, we can conclude that, based on their spatial representation in the territory, ecostabilization measures need to be implemented mainly in the central and southern part of the cadastral area.

The TSES concept was assessed at The Institute of Landscape Ecology of the Slovak Academy of Science (ILE SAS). This focused on the examination of legislative regulations and experience with both the guidelines for creating TSES developed from field research and from specific TSES projects. Here, Buček (2013) [2] supports our assessment that TSES improvements will ensure at least the minimum space for nature in the cultural landscape. This is possible even in an intensively used landscape where natural elements must be gradually supplemented with newly established bio-centres, bio-corridors and interaction elements.

Spatial planning with applied integrated management principles can maintain the greatest national positive socio-economic factors and elements.

From the point of view of the municipality of Dolný Lopašov and its calculated value of the coefficient of ecological stability (Miklós et al., 2020) [24,28], we can state that the spatial arrangement of the territory in the municipality is moderately stabilized and provides preconditions for its sustainable development. The relatively high proportion of PSEP located mainly in the northern part of the cadastral area also contributes to this. From this aspect, it is necessary to design and implement ecological measures, especially in the central and southern part of the cadastral area.

The paper is the resultant solution of VEGA grant project No. 2/0011/21 “Landscape ecological aspects of green and blue infrastructure in the creation of an optimal spatial basis of ecologically stable areas in urbanized land and ITMS 26220220066 Integrated system for simulation of runoff conditions".

Author Contributions: Conceptualization, R.R.; and M.M.; methodology, M.M.; software, R.R.; validation, R.R. and M.M.; formal analysis, R.R. and M.M.; investigation, R.R. and M.M.; resources, R.R. and M.M.; data curation, R.R. and M.M.; writing-original draft preparation, R.R. and M.M.; writing—review and editing, R.R. and M.M.; visualization, R.R.; supervision, R.R. and M.M.; project administration, R.R. and M.M.; funding acquisition, ESPRIT s.r.o. All authors have read and agreed to the published version of the manuscript.

Funding: This research received no external funding.

Institutional Review Board Statement: Not applicable.

Informed Consent Statement: Not applicable.

Data Availability Statement: We obtained data from literary sources, the archive, departmental databases, legislative regulations and methods of structured observations of phenomena in a certain category of protection.

Conflicts of Interest: The authors declare no conflict of interest.

\section{References}

1. Boitani, L.; Falcucci, A.; Maiorano, L.; Rondinini, C. Ecological Networks as Conceptual Frameworks or Operational Tools in Conservation. Conserv. Biol. 2007, 21, 1414-1422. [CrossRef] [PubMed]

2. Buček, A. Ekologická Sit' Jako Přrodní Infrastruktura Kulturní Krajiny; Životné Prostredie: Bratislava, Slovakia, 2013; Volume 47, pp. 82-85.

3. Buček, A.; Lacina, J. Biogeografický Př́stup k Vytváření Územních Systému Ekologickej Stability Krajiny; Czech Republic, Zprávy Geografického ústavu ČSAV Brno: Brno, Czech Republic, 1984; pp. 27-35.

4. Míchal, I. Ekologická Stailita; Veronia: Brno, Czech Republic, 1994; p. 244.

5. Buček, A.; Lacina, J. Územni Systémy Ekologické Stability; Veronia: Brno, Czech Republic, 1993; Volume 8, p. 48.

6. Maděra, P. Ekologické Síte v České Republice-Současný Stav a Perspektivy; Revue pre teóriu a starostlivost' o životné prostredie; Životné Prostredie: Bratislava, Slovakia, 2010; pp. 121-123. 
7. Miklós, L. Siete v Krajine-Územný Systém Ekologickej Stability; Životné Prostredie: Bratislava, Slovakia, 2010; Volume 44, pp. 115-120.

8. Miklós, L. Ekologický Generel ČSSR; Čast' SSR. I. etapa: Priestorová diferenciácia územia z ekologického hl'adiska Záverečná správa P16-121-402/01. Bratislava ÚEBE CBEV SAV, Banská Bystrica: Stavoprojekt; ČSŽP. Bratislava: Bratislava, Slovakia, 1985; p. 152.

9. Húsenicová, J.; Ružičková, J.; Klinda, J.; Miklós, L. Generel Nadregionálneho Územného Systému Ekologickej Stability Slovenskej Republiky; SKŽP: Bratislava, Slovakia, 1992.

10. Návrh Národnej Ekologickej Siete Slovenska-NECONET; Nadácia IUCN, Svetová únia ochrany prírody, Slovensko, v rámci projektu Regionálneho európskeho programu IUCN v Cambrige, Vel'kej Británii a Gland; IUCN: Bratislava, Slovakia, 1996 ; p. 371.

11. Jongman, R.H.G. Nature conservation planning in Europe: Developing ecological networks. Landsc. Urban Plan. 1995, 32, 169-183. [CrossRef]

12. Bennett, G. Towards a European Ecological Network; Institute for European Environmental Policy: Arnheim, Australia, 1991.

13. Bennett, G. ECONET and the Wildlands Project. In Proceedings of the European North American Workshop; Institute for European Environmental Policy: Lisbon, Portugal, 1995.

14. Colmenares, R.; Jose, M.; Díaz, P. ECONET and Grasslands; Kluwer Academic Publishers: London, UK, 1994.

15. Salman, A.H.P.M. ECONET and Coastal Areas and Wetlands: The Golden Fringe of Europe; Conserving Europe's Natural Heritage; Towards a European Ecological Network; International Union for Conservation of Nature: Grand, Switzerland, 1993 ; Volume 912.

16. Gleichman-Verheijen, C. The Development of ECONET through National and International Programmes. In Conserving Europe's Natural Heritage: Towards a European Ecological Network 25; Springer: Berlin, Germany, 1994; p. 169.

17. Stuffmann, C. The European Community and ECONET; Conserving Europe's Natural Heritage: Towards a European Ecological Network; Graham and Trotman: London, UK, 1994.

18. Liro, A. National Ecological Network ECONET-Poland, IUCN European Programme; IUCN-Poland: Warzaw, Poland, 1995.

19. Horlings, I.; Jaap, G. Agriculture and Nature in Ecological Networks in the Netherlands and Europe; University of Nijmegen: Nijmegen, The Netherlands, 1995; Volume 5, pp. 7-12.

20. Jongman, R.H.G.; Mart, K.; Ib, K. European Ecological Networks and Greenways. Landsc. Urban Plan. 2004, 68, 305-319. [CrossRef]

21. Ferranti, F.; Raoul, B.; Maria, S. Natura 2000 Network: A Comparison of the Italian and Dutch Implementation Experiences. J. Environ. Policy Plan. 2010, 12, 293-314. [CrossRef]

22. Act no. 543/2002 Coll. of Nature and Landscape Protection. Available online: https://www.zakonypreludi.sk/zz/2002-543 (accessed on 1 March 2021).

23. Špulerová, J.; Izakovičová, Z.; Miklós, L.; Miklósová, V.; Moyzeová, M.; Raniak, A.; Štefunková, D.; Vlachovičová, M.; Rákayová, R.; Špilárová, I.; et al. Miestny Územný Systém Ekologickej Stability Obce Dolný Lopašov; Ústav krajinnej ekológie SAV; ESPRIT: Banská Štiavnica, Slovakia; SAŽP: Banská Bystrica, Slovakia, 2020; p. 138.

24. Miklós, L.; Kočický, D.; Izakovičová, Z.; Špulerová, J.; Kanka, R.; Štefunková, D.; Miklósová, V.; Moyzeová, M.; Kozelová, I.; Pondelík, R. Návrh Algoritmov Pre Jednotlivé Časti Dokumentov MÚSES: Spracovanie Dokumentov MÚSES Pre Potreby Vytvorenia Základnej Východiskovej Bázy Pre Reguláciu Návrhu Budovania Zelenej Infraštruktúry; Záverečná správa etapy, Product 2; Ústav krajinnej ekológie SAV: Bratislava, Slovakia; ESPRIT: Banská Štiavnica, Slovakia; SAŽP: Banská Štiavnica, Slovakia, 2020 ; p. 213.

25. Kolektív, A. Encyklopédia Miest a Obcí Slovenska; PS-LINE: Lučenec, Slovakia, 2005; p. 960. ISBN 80-969388-8-6.

26. Mazúr, E.; Lukniš, M. Geomorfologické členenie SSR a ČSSR. In Atlas Krajiny Slovenskej Republiky; Ministerstvo životného prostredia SR, Banská Bystrica; Slovenská Agentúra Životného Prostredia: Bratislava, Slovakia, 1986.

27. Malík, P.; Švasta, J. Hlavné hydrogeologické region. In Atlas Krajiny Slovenskej Republiky; Ministerstvo životného prostredia SR, Banská Bystrica; Slovenská Agentúra Životného Prostredia: Bratislava, Slovakia, 2002; pp. 104-105.

28. Miklós, L.; Kočický, D.; Izakovičová, Z.; Špulerová, J.; Kanka, R.; Štefunková, D.; Miklósová, V.; David, S.; Moyzeová, M.; Kozelová, I.; et al. Metodika na Automatizované Generovanie Dokumentov MÚSES: Spracovanie Dokumentov MÚSES Pre Potreby Vytvorenia Základnej Východiskovej Bázy Pre Reguláciu Návrhu Budovania Zelenej Infraštruktúry; Ústav krajinnej ekológie SAV: Bratislava, Slovakia; ESPRIT: Banská Štiavnica, Slovakia; SAŽP: Banská Štiavnica, Slovakia, 2020; p. 279.

29. Ružička, M.; Miklós, L. Landscape-Ecological Planning (LANDEP) in the Process of Territorial Planning; Ekológia (ČSSR): Bratislava, Slovakia, 1982; pp. 297-312.

30. Jančura, P. A kol.: "Manual k Metodike USES, I.-V. diel"; Slovenska agentura životneho prostredia, Odbor uzemneho rozvoja a architektury: Banska Bystrica, Slovakia, 1994; 214p.

31. Löw, J. Zásady Pro Vymezování a Navrhování Územních Systémů Ekologické Stability v Územně-Plánovací Praxi; Agroprojekt: Brno, Czech Republic, 1984; p. 55.

32. Tremboš, P. Miestne Systémy Ekologickej Stability Vo Vybraných Katastrálních Územích v Dosahu Závodu SNP, a. s. Žiar nad Hornom, 2nd ed.; Projekt MŽP SR: Bratislava, Slovakia; GEOINFO: Piešt'any, Slovakia, 1997.

33. Minár, J.; Tremboš, P. Evaluation of the Natural Hazard in the Landscape Planning; Acta Environmentalica Universitatis Comenianae: Bratislava, SLovakia, 1995; pp. 211-222.

34. Ružička, M.; Hrnčiarová, T. Metóda Klasifikácie Ekologickej Stability Územia; Životné Prostredie: Bratislava, Slovakia, 1995; pp. 249-259. 
35. Hrnčiarová, T.; Izakovičová, Z. Environmental Approaches to Sustainable Development; Združenie Krajina 21: Bratislava, Slovakia, $2000 ;$ p. 252.

36. Miklós, L.; Izakovičová, Z. Krajina Ako Geosystém; VEDA, SAV: Bratislava, Slovakia, 1997; p. 152.

37. Miklós, L. The Concept of the Territorial System of Ecological Stability in Slovakia; Jongman, R.H.G., Ed.; Ecological and Landscape Consequences of Land-Use Change in Europe; ECNC Publication Series on Man and Nature: Tilburg, The Netherlands, 1996.

38. Izakovičová, Z.; Hrčiarová, T.; Miklós, L.; Tremboš, P.; Ružičková, J.; Liška, M.; Králik, J.; Moyzeová, M.; Šíbl, J.; Pauditšová, E. Metodické Pokyny Na Vypracovanie Projektov Regionálnych ÚSES a Miestnych ÚSES; Združenie Krajina 21: Bratislava, Slovakia, 2000; p. 111.

39. Izakovičová, Z.; Miklós, L.; Moyzeová, M.; Špilárová, I.; Kočický, D.; Halada, L'.; Gajdoš, P.; Špulerová, J.; Baránková, Z.; Štefunková, D.; et al. Model Reprezentatívnych Geoekosystémov Na Regionálnej Úrovni; Ústav Krajinnej Ekológie SAV: Bratislava, Slovakia, 2011; p. 86.

40. Izakovičová, Z.; Moyzeová, M. Analýza Skúseností S Tvorbou ÚSES v SR; Geobiocenologické Spisy: Bratislava, Slovakia, 2002; pp. 233-236.

41. Anděl, P. Fragmentace Krajiny Dopravní Infrastrukturou a Její Vliv Na Migrační Podmínky Živočichú, 2nd ed.; Životné Prostredie: Bratislava, Slovakia, 2013; pp. 90-94.

42. Koncepcia Územného Rozvoja Slovenska; AUREX s.r.o.: Bratislava, Slovakia; MŽP SR: Bratislava, Slovakia, $2001 ;$ p. 135.

43. Ministry of the Environment of the Slovak Republic. Methodical Instructions for the Elaboration of Documents of the Territorial System of Ecological Stability; Ministry of the Environment of the Slovak Republic: Bratislava, Slovakia, 1993; p. 63.

44. Šteffek, J.; Múdry, P. Metodické Pokyny Pre Vypracovanie Dokumentov ÚSES; SAV: Bratislava, Slovakia, 1993 ; p. 63.

45. Bohálová, I. (Ed.) Metodické Pokyny na Vypracovanie Dokumentov RÚSES; SAŽP: Banská, Bystrica, $2014 ;$ p. 90.

46. Kolektív, A. Návrh Pokynu MŽP SR na Vypracovanie Projektov Regionálnych a Miestnych Územných Systémov Ekologickej Stability; Ministry of Environment of the Slovak Reoublic: Bratislava, Slovakia, 1999.

47. Pauditšová, E.; Reháčková, T.; Ružičková, J. Metodický Návod Na Vypracovanie Miestneho Územného Systému Ekologickej Stability; Acta Environmentalica Universitatis Comenianae: Bratislava, Slovakia, 2007; Volume 15, pp. 66-87.

48. Decree of the Ministry of the Environment of the Slovak Republic no. 24/2003 Coll., Which Implements Act no. 543/2002 Coll., Nature and Landscape Protection. Available online: https:/ /www.slov-lex.sk/pravne-predpisy/SK/ZZ/2003/24/20150101 (accessed on 1 March 2021).

49. Decree of the Ministry of the Environment of the Slovak Republic no. 492/2006 Coll., Amending the Decree of the Ministry of the Environment of the Slovak Republic no. 24/2003 Coll., Which Implements Act no. 543/2002 Coll. on Nature and Landscape Protection. Available online: https:/ / www.slov-lex.sk/pravne-predpisy/SK/ZZ/2006/492/ (accessed on 1 March 2021).

50. Miklós, L.; Diviaková, A.; Izakovičová, Z. Ekologické Siete a Územný Systém Ekologickej Stability; Vydavatel'stvo Technická univerzita vo Zvolene: Zvolen, Slovakia, 2011; p. 141.

51. Miklós, L.; Izakovičová, Z. Neviditel'ná/Nehmotná Infraštruktúra v Krajine. Environ. Rev. Theory Care Environ. $2013,47,72-81$.

52. Petrovič, F. Prognóza Krajiny s Rozptýleným Osídlením. In Česká Geografie v Evropském Prostoru; Kraft, S., Mičková, K., Rypl, J., Švec, P., Vančura, M., Eds.; Sborník z 21. sjezdu ČGS; Jihočeská Univerzita: České Budějovice, Czech Republic, 2007; pp. 474-480. ISBN 978-80-7040-986-2.

53. Moyzeová, M.; Miklós, L.; Šatalová, B.; Izakovičová, Z.; Oszlányi, J.; Kenderessy, P.; Štefunková, D.; Krnáčová, Z. Hodnotenie Kvality Životného Prostredia; Ústav Krajinnej Ekológie SAV: Bratislava, Slovakia, 2015; p. 280.

54. Jurko, A. Ekologické a Socioekonomické Hodnotenie Vegetácie, 1st ed.; Príroda: Bratislava, Slovakia, 1990; p. 200.

55. Odum, E.P. Základy Ekológie; Academia Praha: Praha, Czech Republic, 1975; p. 736.

56. Nowicki, P.; Bennet, G.; Middleton, D.; Rientjes, S.; Wolters, R. (Eds.) Perspectives on Ecological Networks; Uuropean Centre for Nature Conservation: Tilburg, The Netherlands, 1996; p. 192. 